UDK: 342.51(497.5)

Pregledni članak

Primljen 6. XI. 2017.

Miljenko Brekalo

Institut društvenih znanosti Ivo Pilar, Područni centar Osijek

miljenko.brekalo@pilar.hr

\title{
PRAVNI ASPEKTI IMENOVANJA POVJERENIKA VLADE REPUBLIKE HRVATSKE U OPĆINI PODRAVSKA SLATINA
}

\section{Sažetak}

Srpska demokratska stranka (akr. SDS) bila je radikalna, etnonacionalistička stranka srpskoga puka koja je osnovana 17. veljače 1990. na platou ispred Željezničkoga kolodvora u Kninu, a 6. ožujka 199o. upisana je u Registar društvenih organizacija SR Hrvatske. Osnivačkoj skupštini nazočilo je sedam tisuća građana srpske nacionalnosti koji su aklamacijom podržali pročitani programski dokument. SDS osnovao je akademik Jovan Rašković, šibenski psihijatar, pod „dirigentskom palicom“ srbijanske Službe državne bezbednosti (akr. SDB), na čijem se čelu u to vrijeme nalazio haški optuženik Jovica Stanišić, vjerni Miloševićev sljedbenik. SDS je imao vodeću političku ulogu u ratnim događanjima u Hrvatskoj i Bosni i Hercegovini. Njezini su članovi organizirali naoružavanje Srba, podržavali ubijanje, protjerivanje i druge ratne zločine protiv pripadnika nesrpskoga puka na području Hrvatske i Bosne i Hercegovine. Općinski je odbor SDS-a za Općinu Podravska Slatina na čelu s Milunom Karadžićem na području Općine Podravska Slatina organizirao naoružavanje srpskoga puka, iskazao građanski neposluh i blokirao rad Općinske skupštine Podravska Slatina. Nakon SDS-ove blokade rada Izvršnoga vijeća Općinske skupštine Podravska Slatina reagirao je ministar pravosuđa i uprave Branko Babac. On je 24. srpnja 1991. donio Naredbu o poduzimanju posebnih mjera u općini Podravska Slatina kojom je raspu- 
štena Skupština Općine Podravska Slatina, a istovremeno je imenovao povjerenika Vlade Republike Hrvatske.

Ključne riječi: Republika Hrvatska; Srpska demokratska stranka; Općina Podravska Slatina; Izvršno vijeće Općinske skupštine Podravska Slatina; povjerenik Vlade Republike Hrvatske; Služba državne bezbednosti

\section{Uvod}

Područje bivše Općine Podravska Slatina nalazi se na sjeverozapadu Slavonije, a prostiralo se dijelom na dravskoj nizini i sjevernim padinama Papučkoga gorja. Omeđeno je na istoku rječicama Vojlovicom i Voćinkom, na sjeveru rijekom Dravom, na zapadu potokom Breznicom, a na jugu vrhovima planine Papuk. Podravsko-slatinski kraj graniči na sjeveru s Republikom Mađarskom, na sjeverozapadu s Općinom Virovitica, na jugozapadu s Općinom Daruvar, na jugu s Općinom Slavonska Požega, na istoku s Općinom Orahovica, a na sjeveroistoku s Općinom Donji Miholjac. ${ }^{1}$

Tijekom prve tri godine nakon izbora za Sabor RH, održanih 22. travnja 1990., a sve do 1993., mjesna je samouprava zadržala institucionalni oblik naslijeđen iz prethodnoga, socijalističkog razdoblja. Svoj raniji naziv i organizaciju zadržale su teritorijalne jedinice i organizacije kao i njihova predstavnička i izvršna tijela. Tada je postojalo sto općina i Grad Zagreb kao jedinstvena općina sve do 1. siječnja 1991. Predstavnička tijela bile su skupštine općina i one su birale svoja izvršna vijeća na čelu s predsjednikom izvršnoga vijeća. Skupštine su bile trodomne, sastavljene od Vijeća udruženoga rada (VUR), Društveno-političkoga vijeća (DPV) i Vijeća mjesnih zajednica (VMZ). U tome su institucionalnom okviru bili provedeni i prvi višestranački izbori u svibnju 1990., a na kojima su izabrani odbornici i zastupnici u skupštine općina, skupštine zajednica općina i Sabor. 29. prosinca 1992. doneseno je pet zakona kojima je provedena nova teritorijalna podjela Republike Hrvatske. Tada je uveden sustav mjesne samouprave i uprave kao i izbor za članove predstavničkih tijela u novoformiranim jedinicama. Formirano je 418 općina i 69 gradova na razini lokalne samouprave te 20 županija na razini lokalne samouprave i uprave. Pored toga utemeljena su dva autonomna kotara, Knin i Glina, na području s većim udjelom srpskoga pučanstva. Međutim, navedeni kotari nikada nisu počeli funkcionirati zbog rata i kasnijih institucionalnih promjena. Odredbama Ustava RH (Narodne novine, br. 56/199o.) i Zakona o područjima županija, gradova i općina u Republici Hrvatskoj (Narodne novine, br. 90/1992.) u Republici Hrvatskoj uvedena je nova političko-teritorijalna podjela na županije, gradove i općine. Prema tome, područje nekadašnje Općine Podravska Slatina podijeljeno je na Grad Slatinu i sljedeće općine: Voćin, Milkeuš, Nova Bukovica, Sopje i Čađavica. 
Općina Podravska Slatina prostirala se na $781 \mathrm{~km}^{2}$, a sastojala se od 69 naselja. Njezinim nizinskim dijelom prolaze dvije važne komunikacije, podravska željeznička magistrala i podravska cestovna magistrala, koje su bile od vitalna značaja tijekom trajanja Domovinskoga rata, naročito za vrijeme agresorske blokade autoceste Zagreb - Beograd kod Okučana. ${ }^{2}$

Južni su dijelovi slatinskoga područja bregoviti i šumoviti, a na sjeveru se prostire podravska nizina. Brdski kraj obuhvaća mnoštvo sjevernih obronaka i vrhova planine Papuk, obraslih većim dijelom bjelogoričnom šumom, te pitome planinske kotline, doline i visoravni koje su pogodne za poljoprivrednu aktivnost. Ravničarski predjeli ovoga kraja prostiru se na desnoj obali rijeke Drave. Tu se prostiru obradiva polja i livade koje su na mjestima ispresijecane manjim kompleksima ravničarske hrastove i jasenove šume.

\section{Nacionalna struktura u Općini Podravska Slatina 1991.}

Prema tome, područje nekadašnje Općine Podravska Slatina zemljopisno se dijeli na dva dijela: brdski dio, tzv. Brđansku, i nizinski dio, tzv. Podravinu. U Brđanskoj pretežito su živjeli pripadnici srpskoga puka, a u Podravini dominantno su bili zastupljeni Hrvati.

U bivšoj Općini Podravska Slatina, prema popisu pučanstva iz 1991. godine, živjelo je 15445 pučana, od toga broja 9219 (59,6 \%) bili su $\mathrm{Hr}$ vati, 4948 (32 \%) Srbi i 1278 (8,3\%) ostali. Srbi su bili dominantni u Brđanskoj, ${ }^{3}$ gdje je živjelo 3262 pripadnika srpske nacionalnosti, 668 Hrvata i 222 ostala građanina. ${ }^{4}$

2 Usp. Domagoj ŠTefančıć, „Autocesta - okosnica rata u zapadnoj Slavoniji“, Radovi Zavoda za hrvatsku povijest Filozofskoga fakulteta Sveučilišta u Zagrebu, Zagreb. god. XLIII. (2011.) br. 1., str. 427-455.

3 Brđansku je sačinjavao kompleks od dvadeset i jednoga sela na području planine Papuk, a od toga broja, prema popisu pučanstva iz 1991. godine, u dvadeset sela Srbi su činili većinsko pučanstvo. Brđanska su sela nakon uvođenja mjesne samouprave u Republici Hrvatskoj 1992. ušla u sastav novoformirane Općine Voćin.

4 Usp. Juraj HržEnjaK, Lokalna samouprava i uprava u Republici Hrvatskoj, Informator, Zagreb, 1993., str. 363-375. 
Ovaj je zemljopisni lokalitet predstavljao rubno područje tzv. Velike Srbije. Naime, on graniči s virovitičkim područjem gdje su srpski ekstremisti i separatisti zacrtali granicu na pravcu Virovitica - Karlovac - Karlobag. Granicu navedene paradržavne tvorevine potvrđuju riječi, s početka devedesetih godina prošloga stoljeća, najviše rangiranoga časnika JNA i tadašnjega sekretara (ministra) za narodnu obranu SFRJ-a, generala armije Veljka Kadijevića: „Smjerove napada glavnih snaga JNA što izravnije vezivati uz oslobođenje srpskih krajeva u Hrvatskoj i garnizona JNA u dubini hrvatskog teritorija. U tom cilju ispresijecati $\mathrm{Hr}$ vatsku na pravcima: Gradiška - Virovitica, Bihać - Karlovac - Zagreb, Knin - Zadar, Mostar - Split."

Pored Brđanske, do Domovinskoga rata velik broj pripadnika srpske nacionalnosti na slatinskome je području živio u Slatini (4 270), Petrovacu (453), Mikleušu (345) i Španatu (327). ${ }^{6}$

\section{Stranačka infrastruktura SDS-a na slatinskome području}

Inicijativni odbor Srpske demokratske stranke za Općinu Podravska Slatina organizirao je 9. lipnja 1990. godine od 16 do 19 sati okupljanje građana ispred slatinske kinodvorane, gdje je Osnivačkoj skupštini SDS-a nazočilo pet tisuća građana srpske nacionalnosti s područja općina: Podravska Slatina, Donji Miholjac, Orahovica, Virovitica i Slavonska Požega. Nazočnima su govorili: predsjednik SDS-a akademik Jovan Rašković, potpredsjednik SDS-a Milan Vujnović, član Glavnoga odbora SDS-a Jovan Opačić, predsjednik Regionalnoga odbora SDS-a Ilija Sašić, predsjednik Inicijativnoga odbora za Općinu Podravska Slatina Milun Karadžić i drugi članovi Inicijativnoga odbora sa slatinskoga područja. Tom prigodom optužili su službenu hrvatsku vlast za kroatocentričnost i ustaštvo, a predstavnike hrvatskoga političkog života, na čelu s doktorom Franjom Tuđmanom, za nacionalnu mržnju, razdor i netrpeljivost između građana hrvatske i srpske nacionalnosti.

\footnotetext{
5 Veljko Kadijević, Moje viđenje raspada - vojska bez države, Politika izdavačka delatnost, Beograd, 1993., str. 128.

6 Usp. J. HrŽENJAK, $n$. dj., str. 370-372.
} 
Na Osnivačkoj skupštini SDS-a izabran je Općinski odbor Srpske demokratske stranke za Općinu Podravska Slatina, ${ }^{7}$ koji su činili:

- Jovan (Save) Bojčić, Srbin, dipl. ing. graditeljstva iz Podravske Slatine, član

- Nikola (Milana) Dopuđa, Srbin, dipl. ing. agronomije iz Španata, Općina Podravska Slatina, član

- Milun (Petra) Karadžić, Crnogorac, dipl. iur. i dipl. politolog iz Podravske Slatine, predsjednik

- Ilija (Jovana) Sašić, Srbin, odvjetnik iz Podravske Slatine, član

- Vladimir (Petra) Šimpraga, Srbin, dipl. ing. šumarstva iz Podravske Slatine, član

- Momčilo (Ljubomira) Subotić, Srbin, srednjoškolski profesor iz Podravske Slatine, potpredsjednik

- Mirko (Obrada) Vujanić, Srbin, službenik (SSS) iz Aleksandrovca, Općina Podravska Slatina, član

- Ratko (Petra) Vukelić, Srbin, srednjoškolski profesor iz Španata, Općina Podravska Slatina, član. ${ }^{8}$

\section{Lokalni izbori u Općini Podravska Slatina 1990.}

Posljednji izbori za Općinsku skupštinu Podravska Slatina, ${ }^{10}$ prije uvođenja nove političko-teritorijalne podjele Republike Hrvatske na

MUP RH, Policijska uprava Osijek, Policijska stanica Podravska Slatina, pismeno br.: 511-o76o-KU-490/1992., str. 1-3.

8 N. Stanković, „Zajedništvo bilo i ostalo sudbina“, Glas Slavonije, Osijek, br. 13836., 11. lipnja 1990., str. 2.

9 S. Sarkanjac, „Mi nismo HDZ na srpski način“, Glas Slavonije, Osijek, br. 13841., 16. lipnja 1990., str. 12.

10 Tijekom postojanja SFRJ-a skupština općine ili općinska skupština bila je tijelo (organ) društvenoga samoupravljanja i najviše tijelo (organ) vlasti u okviru prava i dužnosti općine. Sastav, organizacija i nadležnost skupštine općine i njoj odgovornih tijela bila je utvrđena statutom općine na osnovi jedinstvenih načela delegatskoga skupštinskog sustava, utvrđenih Ustavom SFRJ-a i ustavima socijalističkih republika i autonomnih pokrajina kao i na osnovi zakona. 
županije, gradove i općine, ${ }^{11}$ prema odredbama Zakona o područjima općina u Republici Hrvatskoj, ${ }^{12}$ provedeni su u dva kruga; prvi je krug održan 22. i 23. travnja 1990. godine, a drugi dva tjedna kasnije, odnosno 6. i 7. svibnja.

Prema tadašnjoj je legislativi Općinska skupština Podravska Slatina bila trodomna, a sastojala se od Vijeća udruženoga rada, Društveno-političkoga vijeća i Vijeća mjesnih zajednica. Ukupno je brojila devedeset odbornika, a od toga broja Vijeće udruženoga rada sastojalo se od četrdeset, Društveno-političko vijeće od dvadeset i Vijeće mjesnih zajednica od trideset odbornika. U to vrijeme, na temelju odredaba Statuta Općine Podravska Slatina, ${ }^{13}$ Općinska skupština Podravska Slatina birala je svoga predsjednika, članove i predsjednika Izvršnoga vijeća Općinske skupštine Podravska Slatina. Izvršno vijeće sastojalo se od predsjednika i deset članova. Kandidata za predsjednika Izvršnoga vijeća predlagala je Komisija za izbor i imenovanja na osnovi konzultacije, a za kojega se prethodno utvrdilo da uživa povjerenje većine odbornika Općinske skupštine. Nakon toga kandidat za predsjednika Izvršnoga vijeća iznio bi svoj program na zajedničkoj sjednici svih vijeća Općinske skupštine. Izabrani predsjednik Izvršnoga vijeća Općinske skupštine ujedno je bio i mandatar za sastav Izvršnoga vijeća, koje je birala Općinska skupština na sjednici svih vijeća tajnim glasovanjem, natpolovičnom većinom glasova ukupnoga broja odbornika.

Tijekom provođenja izbora Općinska izborna komisija, na čelu s predsjednikom Matom Krpačićem, ${ }^{14}$ izvršila je sve tehničke pripreme

${ }_{11}$ Prije uvođenja mjesne samouprave, odnosno područne (regionalne) samouprave, u Republici Hrvatskoj postojao je komunalni sustav gdje je osnovni organizacijski oblik bila općina, odnosno osnovna društveno-politička zajednica. Osnovni položaj, prava i dužnosti općine bili su utvrđeni Ustavom SFRJ-a (čl. 116-119.) i ustavima svih socijalističkih republika i socijalističkih autonomnih pokrajina.

${ }_{12}$ Narodne novine, br. 39/1962., 5/1963., 13/1965., 54/1965., 27/1967., 8/1968., 20/1968., 21/1968., 30/1970., 44/1970., 48/1970, 11/1973., 8/1974., 42/1974., 1/1975., 9/1978., 31/1980., 41/1981., 8/1986., 27/1988., 47/1990. i 9/1992.

13 Službeni glasnik općine Podravska Slatina, br. 1/1974., 1/1976., 5/1978., 1/1982., 6/1984. i 5/1986.

${ }_{14}$ Predsjednik Općinske izborne komisije bio je Mato Krpačić koji je u to vrijeme obnašao dužnost predsjednika Općinskoga suda u Podravskoj Slatini, a članovi su bili: Nikola Lipić, Mila Sašić, Rajko Milinović i Branko Šakić. 
za izbore i skrbila za zakonito provođenje svih izbornih radnji. Komisija je organizirala 74 biračka mjesta na području općine i 57 biračkih mjesta u društvenim poduzećima i zajednicama te imenovala isti broj biračkih odbora. U provedbi izbora izravno je sudjelovalo, što kao članovi biračkoga odbora ili njihovih zamjenika, ukupno 786 osoba. Istovremeno, na osnovi pravovaljanih prijedloga kandidata Općinska izborna komisija donijela je najprije 90 deklaratornih odluka o tome koji su predloženi kandidati utvrđeni kao kandidati izborne jedinice za izbor odbornika. $\mathrm{Na}$ temelju spomenutih odluka Komisija je utvrdila liste kandidata koje su službeno objavljene putem Radijske postaje Podravska Slatina i putem općih oglasa u svim mjesnim zajednicama na području komune. Navedeni poslovi izvršeni su u roku od tri dana od posljednjega dana za predaju prijedloga kandidata za odbornika, a na utvrđene i objavljene liste kandidata nije bilo u zakonskome roku podnijetih prigovora kandidata ili birača.

U provedenome postupku kandidiranja utvrđeno je ukupno dvjesto trideset kandidata za odbornike Općinske skupštine, i to:

- za Vijeće udruženoga rada devedeset jedan kandidat

- za Vijeće mjesnih zajednica osamdeset jedan kandidat

- za Društveno-političko vijeće pedeset osam kandidata.

Stranačka struktura kandidata bila je sljedeća:

- SKH - Stranka demokratskih promjena - sto devet kandidata

- SSH - Savez socijalista - četrdeset pet kandidata

- Hrvatska demokratska zajednica - četrdeset četiri kandidata

- Nezavisni kandidati - trideset dva kandidata. ${ }^{15}$

Nakon što su zaprimljeni izborni materijali sa svih biračkih mjesta na području općine, Općinska izborna komisija utvrdila je da je u prvome izbornom krugu za odbornike Općinske skupštine izabrano pedeset osam kandidata ili $64,44 \%$, a prema vijećima to je bila sljedeća zastupljenost odbornika:

${ }^{15}$ „Izvještaj o tijeku i rezultatima izbora za odbornike u sva tri vijeća Općinske skupštine“, Službeni glasnik općine Podravska Slatina, br. 5/1990., str. 299. 
- za Vijeće udruženoga rada dvadeset pet kandidata ili 62,50 \%

- za Vijeće mjesnih zajednica dvadeset jedan kandidat ili 70,00\%

- za Društveno-političko vijeće dvanaest kandidata ili 60,00 \%. ${ }^{16}$

U prvome je izbornom krugu, od ukupno upisanih 15700 birača, za Vijeće udruženoga rada glasovalo 14146 birača ili 90,11 \%, a za Vijeće mjesnih zajednica i Društveno-političko vijeće, od ukupno upisanih 23 133 birača, glasovalo je 21006 ili 9o,81 \%. ${ }^{17}$

U drugome je izbornom krugu, od ukupno upisanih 6436 birača, za Vijeće udruženoga rada glasovalo 5457 birača ili 84,94 \%; za Društveno-političko vijeće, od ukupno upisanih 9681 birača, glasovalo je 8261 birača li 85,33 \%; za Vijeće mjesnih zajednica, od ukupno upisanih 9382 birača, glasovalo je 7858 birača ili $83,76 \%{ }^{18}$

Stranačka je struktura nakon provedenih izbora u Vijeću udruženoga rada Općinske skupštine Podravska Slatina bila sljedeća:

- dvadeset sedam odbornika iz redova SKH-a - Stranke demokratskih promjena ili $67,50 \%$

- šest odbornika iz redova Hrvatske demokratske zajednice ili $15 \%$

- dva odbornika iz redova Socijalističkoga saveza - Saveza socijalista ili $5 \%$

- pet odbornika iz redova Nezavisnih kandidata ili 12,50 \%. ${ }^{19}$

Stranačka je struktura nakon provedenih izbora u Vijeću mjesnih zajednica Općinske skupštine Podravska Slatina bila sljedeća:

- četrnaest odbornika iz redova SKH-a - Stranke demokratskih promjena ili 43,33\%

- trinaest odbornika iz redova Hrvatske demokratske zajednice ili $15 \%$

- jedan odbornik iz redova Socijalističkoga saveza - Saveza socijalista ili 3,34\% 
- dva odbornika iz redova Nezavisnih kandidata ili 6,67 \%. ${ }^{20}$

Stranačka je struktura nakon provedenih izbora u Društveno-političkome vijeću Općinske skupštine Podravska Slatina bila sljedeća:

- devet odbornika iz redova SKH-a - Stranke demokratskih promjena ili $45 \%$

- deset odbornika iz redova Hrvatske demokratske zajednice ili 50 $\%$

- jedan odbornik iz redova Socijalističkoga saveza - Saveza socijalista ili $5 \%{ }^{21}$

Stranačka je struktura nakon provedenih izbora u sva tri vijeća Općinske skupštine Podravska Slatina bila sljedeća:

- pedeset odbornika iz redova SKH-a - Stranke demokratskih promjena ili 55,56\%

- dvadeset i devet odbornika iz redova Hrvatske demokratske zajednice ili 32,22\%

- četiri odbornika iz redova Socijalističkoga saveza - Saveza socijalista ili 4,44\%

- sedam odbornika iz redova Nezavisnih kandidata ili 7,78 \%. ${ }^{22}$

$\mathrm{Na}$ osnovi rezultata glasovanja u prvome i drugome izbornom krugu za odbornike u sva tri vijeća Općinske skupštine izabrani su sljedeći kandidati iz redova nezavisnih kandidata: Ivan Bajt iz Ciganke, Stjepan Kolomaz iz Podravske Slatine, Milan Kovač iz Sladojevaca, Berislav Kralj iz Podravske Slatine, Božidar Momčilović iz Španata i Jovo Vučković iz Podravske Slatine.

Iz redova HDZ-a izabrani su sljedeći odbornici: Stjepan Babić iz Senkovca, Slavko Boljevac iz Gornjeg Predrijeva, Rudolf Bošnjak iz Čađavice, Josip Butorac iz Četekovca, Stjepan Cibok iz Zvonimirovca, Željko Filković iz Kozica, Tomo Gorenac iz Bakića, Mirko Hess iz Donjih Meljana, Milenko Horvat iz Vaške, Draženko Idek iz Novaka, Zdenko Kiš iz Kozica, Franjo Kostanjevac iz Senkovca, Antun Košćak iz Zvonimirovca,

\footnotetext{
20 Isto, str. 310 .

${ }_{21}$ Isto, str. 310.

22 Isto, str. 311.
} 
Josip Krištan iz Sopja, Tihomir Kukuljević iz Novaka, Zvonimir Lipčić iz Podravske Slatine, Ivan Maras iz Sladojevaca, Zlatko Milošević iz Nove Bukovice, Tomislav Novaković iz Sladojevaca, Josip Njegač iz Čađavice, Ivica Pavin iz Baskića, Nikola Petrak iz Podravske Slatine, Pero Radulović iz Podravske Slatine, Dragan Rastija iz Sopja, Stjepan Sedlar iz Senkovca, Zoran Stipanić iz Podravske Slatine, Jozo Šantak iz Sopja, Ivan Vida iz Noskovaca i Andrija Vukomanović iz Kozica.

Iz redova SKH-a - Stranke demokratskih promjena izabrani su sljedeći odbornici: Zdravko Abadžić iz Voćina, Nenad Avirović iz Podravske Slatine, Petar Bajić iz Podravske Slatine, Julijus Berkić iz Podravske Slatine, Jovan Bojčić iz Podravske Slatine, Rajko Bojčić iz Podravske Slatine, Dragutin Bolić iz Gornjih Meljana, Milan Božinac iz Donjih Kusonja, Radovan Budalić iz Podravske Slatine, Anka Budimir iz Podravske Slatine, Nikola Buzadžić iz Ćeralija, Nikola Čaglić iz Podravske Slatine, Zlatko Čvek iz Podravske Slatine, Čedo Ćopić iz Petrovca, Stanojla Dopuđa iz Podravske Slatine, Mihajlo Fuks iz Podravske Slatine, Rade Gajić iz Podravske Slatine, Petar Ivanišević iz Podravske Slatine, Dušan Janić iz Podravske Slatine, Gojko Jarić iz Mikleuša, Bogdan Jorgić iz Kometnika, Milan Jurišić iz Podravske Slatine, Đuro Klement iz Godnjeg Miholjca, Stevo Kljajić iz Podravske Slatine, Jovan Kokić iz Podravske Slatine, Tihomir Kosanović iz Podravske Slatine, Ivo Lončarević iz Mikleuša, Dušanka Lukić iz Podravske Slatine, Vlado Marović iz Podravske Slatine, Ivan Matota iz Miljevaca, Petar Medvedović iz Medinaca, Božo Opačić iz Podravske Slatine, Slobodan Perić iz Podravske Slatine, Rade Radanović iz Ćeralija, Pane Radmilović iz Podravske Slatine, Đuro Radovjević iz Podravske Slatine, Stevo Radošević iz Voćina, Mirko Radulović iz Podravske Slatine, Josip Rajnović iz Podravske Slatine, Stevan Ratić iz Podravske Slatine, Marko Stanivuković iz Podravske Slatine, Savo Stanivuković iz Voćina, Zdravko Starijaš iz Mikleuša, Rajko Stojnović iz Lisičina, Dobrila Todorović iz Podravske Slatine, Drago Todorović iz Voćina, Radoja Todorović iz Voćina, Vlajko Tomašević iz Podravske Slatine, Mislav Veić iz Medinaca i Miroslav Vujić iz Podravske Slatine.

Iz redova Socijalističkoga saveza - Saveza socijalista izabrani su sljedeći odbornici: Ranko Crnobrnja iz Podravske Slatine, Milan Dlab iz 
Podravske Slatine, Josip Mađarić iz Čađavičkog Luga i Predrag Perlina iz Aleksandrovca. ${ }^{23}$

Nakon provedena oba kruga izbora, 8. lipnja 199o. godine održana je prva zajednička sjednica Vijeća udruženoga rada, Vijeća mjesnih zajednica i Društveno-političkoga vijeća. Tada je Općinska skupština donijela Odluku o sazivanju Komisije za izbor i imenovanje Općinske skupštine Podravska Slatina ${ }^{24}$ koju su sačinjavali: Milan Jurišić iz Podravske Slatine (predsjednik), Rajko Bojčić iz Podravske Slatine, Anka Budimir iz Podravske Slatine, Julijus Berkić iz Podravske Slatine, Josip Njegač iz Čađavice, Antun Košćak iz Zvonimirovca i Ivan Bajt iz Ciganke. ${ }^{25}$ Tom je prigodom za predsjednika Općinske skupštine izabran Rade Gajić iz Podravske Slatine, ${ }^{26}$ a za njegova zamjenika Zlatko Milošević iz Nove Bukovice. ${ }^{27}$ Zlatko Čvek iz Podravske Slatine izabran je za predsjednika Vijeća udruženoga rada, a za njegova zamjenika Jozo Šantak iz Sopja. Stanojla Dopuđa iz Podravske Slatine izabrana je za predsjednicu Vijeća mjesnih zajednica, a za njezina zamjenika Franjo Kostanjevac iz Senkovca. Stjepan Sedlar iz Zvonimirovca izabran je za predsjednika Društveno-političkoga vijeća, a za njegova zamjenika Zdravko Starijaš iz Mikleuša.

Nakon izbora predsjednika Općinske skupštine i predsjednika vijeća i njihovih zamjenika trebalo je u zakonskim i statutarnim rokovima izabrati izvršno tijelo, odnosno Izvršno vijeće Općinske skupštine Podravska Slatina. Uslijed nepovoljne političke klime na slatinskome području navedeni izbor nije ostvaren u zakonskome roku. Zbog toga je Općinska skupština Podravska Slatina pod predsjedavanjem Rade Gajića, na

23 Isto, str. 302-309.

24 „Odluka o sazivanju Komisije za izbor i imenovanje Općinske skupštine Podravska Slatina“, Klasa: 013-03/90-01/31, Ubroj: 2166-01-01-90-1, od 8. lipnja 1990., Službeni glasnik općine Podravska Slatina, br. 5/1990., str. 289.-290.

25 „Rješenje o imenovanju članova Komisije za izbor i imenovanje“, Klasa: 013-03/90-01/30, Ubroj: 2166-01-01-90-1, od 8. lipnja 1990., Službeni glasnik općine Podravska Slatina, br. 5/1990., str. 291-292.

26 „Rješenje o izboru predsjednika Općinske skupštine“, Klasa: 013-03/90-01/33, Ubroj: 216601-01-90-1, od 8. lipnja 1990., Službeni glasnik općine Podravska Slatina, br. 5/199o., str. 290.

27 „Rješenje o izboru zamjenika predsjednika Općinske skupštine“, Klasa: 013-03/90-01/32, Ubroj: 2166-01-01-90-1, od 8. lipnja 1990., Službeni glasnik općine Podravska Slatina, br. 5/1990., str. 291. 
temelju odredaba Zakona o izboru $i$ opozivu odbornika $i$ zastupnika, ${ }^{28}$ 15. listopada 199o. donijela Odluku o raspisivanju prijevremenih izbora za izbor odbornika u Vijeće udruženoga rada, Vijeće mjesnih zajednica $i$ Društveno-političko vijeće Općinske skupštine Podravska Slatina. ${ }^{29} \mathrm{Me}-$ đutim, navedena je Odluka mjesec dana kasnije stavljena izvan snage i prestala je važiti novom Odlukom o prestanku važenja Odluke o raspisivanju prijevremenih izbora za izbor odbornika u Vijeće udruženoga rada, Vijeće mjesnih zajednica i Društveno-političko vijeće Općinske skupštine Podravska Slatina. ${ }^{30}$ Nakon mnogobrojnih političkih konzultacija postignut je dogovor oko izbora predsjednika i članova Izvršnoga vijeća Općinske skupštine Podravska Slatina.

Općinska skupština na svojoj je sjednici 14. prosinca 1990. godine donijela dva rješenja o sastavu, odnosno o izboru Izvršnoga vijeća Općinske skupštine Podravska Slatina. Rješenjem o izboru predsjednika Izvršnoga vijeća Općinske skupštine Podravska Slatina ${ }^{31}$ za predsjednika je izabran Ivan Rastija, nastavnik iz Podravske Slatine, a Rješenjem o izboru članova Izvršnoga vijeća Općinske skupštine Podravska Slatina ${ }^{32}$ za članove su izabrani: Mirko Bukva, diplomirani pravnik; Nikola Dopuđa, diplomirani inženjer; Vladimir Gabrić, diplomirani inženjer; Milan Jurišić, inženjer; Antun Knapić, diplomirani inženjer; Josip Ostrošić, profesor; Ilija Sašić, odvjetnik; Ante Šimara, diplomirani inženjer; Mato

${ }^{28}$ Narodne novine, br. 7/199o.

29 „Odluka o raspisivanju prijevremenih izbora za izbor odbornika u Vijeće udruženoga rada, Vijeće mjesnih zajednica i Društveno-političko vijeće Općinske skupštine Podravska Slatina“, Klasa: 013-03/90-01/54, Ubroj: 2166-01-01-90-1, od 15. listopada 1990., Službeni glasnik Općine Podravska Slatina, br. 8/199o. str. 376.-377.

3o „Odluka o prestanku važenja Odluke o raspisivanju prijevremenih izbora za izbor odbornika u Vijeće udruženoga rada, Vijeće mjesnih zajednica i Društveno-političko vijeće Općinske skupštine Podravska Slatina“, Klasa: 013-03/90-01/54, Ubroj: 2166-o'1-o1-90-2, od 16. studenoga 1990., Službeni glasnik Općine Podravska Slatina, br. 8/199o. str. 38o.

${ }_{31}$ „Rješenje o izboru članova Izvršnog vijeća Općinske skupštine Podravska Slatina“, Klasa: 022-05/90-01/32, Ubroj: 2166-01-01-90-1 od 14. prosinac 1990., Službeni glasnik Općine Podravska Slatina, br. 9/1990. str. 390.

32 „Rješenje o izboru predsjednika Izvršnoga vijeća Općinske skupštine Podravska Slatina“, Klasa: 022-05/90-01/32, Ubroj: 2166-01-01-90-2 od 14. prosinca 1990., Službeni glasnik Općine Podravska Slatina, br. 9/199o. str. 391. 
Tolušić, diplomirani ekonomist i Milorad Turudija, magistar ekonomskih znanosti, svi iz Podravske Slatine.

Novoizabrano Izvršno vijeće Općinske skupštine Podravska Slatina funkcioniralo je od 14. prosinca 1990. do 11. srpnja 1991. godine, kada je održana posljednja i izvanredna sjednica. Na navedenoj sjednici, sukladno nalogu Ministarstva obrane Republike Hrvatske od 8. srpnja 1991. godine, razriješen je Veljko Vukelić s dužnosti sekretara Općinskoga sekretarijata za narodnu obranu Općine Podravska Slatina, a na njegovo je mjesto imenovan Josip Job, profesor obrane i zaštite iz Podravske Slatine. Istovremeno je s dužnosti razriješen i Stamenko Subotić s mjesta komandanta Teritorijalne obrane Općine Podravska Slatina, na njegovo je mjesto imenovan Ivan Roštaš, profesor iz Podravske Slatine, a Dragan Medvedović, dotadašnji radnik Općinskoga sekretarijata za narodnu obranu Podravska Slatina, imenovan je načelnikom Štaba civilne zaštite Općine Podravska Slatina. ${ }^{33}$ Pored razrješenja bivših i imenovanja novih obnašatelja dužnosti, Izvršno vijeće donijelo je zaključak da se Štab teritorijalne obrane (djelatnici, oprema i inventar) premjesti s dotadašnje lokacije (Garnizon JNA Podravska Slatina) u zgradu Općinske skupštine Podravska Slatina, Trg Maršala Tita 10 (danas Trg svetoga Josipa). Tom je prigodom zadužen novoimenovani komandant Teritorijalne obrane da u dogovoru s predsjednikom Izvršnoga vijeća, sekretarom Općinskoga sekretarijata za narodnu obranu i po potrebi s drugim rukovodiocima Općinske uprave, izvrši navedeni zadatak u što kraćem roku koji je objektivno moguć te o tome izvijesti Izvršno vijeće do 19. srpnja 1991. godine. Pored toga, Izvršno vijeće zaključilo je da se od Pete vojne oblasti JNA i Republičkoga štaba Teritorijalne obrane zatraži uvid u skladište oružja koje pripada Teritorijalnoj obrani Općine Podravska Slatina. ${ }^{34}$

Navedena sjednica svojevrsna je uvertira u Domovinski rat na slatinskome području. Prije toga, krajem ožujka 1991. godine rukovodstvo SDS-a počelo je opstruirati rad Izvršnoga vijeća Općinske skupštine

33 „Izvod iz zapisnika s izvanredne sjednice Izvršnoga vijeća Općinske skupštine Podravska Slatina od 11. srpanja 1991. godine", str. 2.-3.

${ }_{34}$ Isto, str. 4. 
Podravska Slatina preko odbornika srpske nacionalnosti, formalno članova SKH-a - Stranke demokratskih promjena, koji su nakon eskalacije svi prešli u Srpsku demokratsku stranku. Naime, od osme sjednice Izvršnoga vijeća koja je održana 19. ožujka 1991. godine, na blagdan svetoga Josipa, Mirko Bukva, Nikola Dopuđa, Milan Jurišić, Ilija Sašić i Milorad Trudija kontinuirano su prestali dolaziti na sjednice Izvršnoga vijeća. ${ }^{35}$ Uslijed njihova opstruiranja i bojkota Skupština Općine Podravska Slatina i Izvršno vijeće bili su vrlo često blokirani u radu. Nakon toga navedenih pet članova SDS-a, na čelu s Radom Gajićem, predsjednikom Skupštine općine Podravska Slatina, dalo je ostavke na članstvo u Skupštini Općine Podravska Slatina i u Izvršnome vijeću Općinske skupštine Podravska Slatina. Uslijed toga, Skupština Općine Podravska Slatina i Izvršno vijeće nisu se mogli sastajati i donositi bitne odluke za djelovanje gospodarstva i tijela državne uprave.

\section{Imenovanje povjerenika Vlade Republike Hrvatske za Općinu Podravska Slatina}

Nakon novonastale političke situacije, blokade rada Izvršnoga vijeća Općinske skupštine Podravska Slatina, reagiralo je Ministarstvo pravosuđa i uprave, odnosno resorni ministar prof. dr. sc. Branko Babac. On je 24. srpnja 1991. godine, na temelju svojih ovlasti, ${ }^{36}$ donio Naredbu o poduzimanju posebnih mjera u općini Podravska Slatina, ${ }^{37}$ kojom je raspuštena Skupština Općine Podravska Slatina, a odbornicima Općinske skupštine prestao je mandat.

35 Od 14. prosinca 1990. do 11. srpnja 1991. godine održano je petnaest redovnih i jedna izvanredna (posljednja) sjednica Izvršnoga vijeća Općinske skupštine Podravska Slatina. Mirko Bukva, Nikola Dopuđa, Milan Jurišić, Ilija Sašić i Milorad Trudija nisu nazočili na 50 \% sjednica.

${ }_{36}$ Na temelju članka 16o. stavka 1. alineje 3. i članka 2. stavka 2. Zakona o upravi, Narodne novine, br. 16/1978., 56/1978., 29/1985., 48/1985., 41/199o. i 47/199o.), u svezi s člankom $17 a$. do 17d. Zakona o Vladi Republike Hrvatske, Narodne novine, br. 16/1978., 56/1978., 29/1985., 48/1985., 41/1990. i 47/1990.), a pozivom na članak 130. Ustava Republike Hrvatske.

37 „Naredba o poduzimanju posebnih mjera u Općini Podravska Slatina“, Klasa: 015-05/9101/16, Urbroj: 514-o1-91-1, Zagreb, 24. srpnja 1991., Narodne novine, br. 36/1991. Ova „Naredba" stupila je na snagu danom objave u Narodnim novinama, odnosno 24. srpnja 1991. godine. 
Danom raspuštanja Skupštine Općine Podravska Slatina razriješeno je i njezino Izvršno vijeće, a istovremeno je predsjedniku i potpredsjednicima Skupštine i predsjedniku i članovima Izvršnoga vijeća prestao radni odnos.

Istoga dana ministar Babac donio je Rješenje o imenovanju povjerenika Vlade u općini Podravska Slatina,$^{38}$ kojim je za povjerenika Vlade Republike Hrvatske imenovan Ante Šimara, dipl. ing. agronomije.

Nakon imenovanja Šimara je preuzeo sve ovlasti, dužnosti i odgovornosti Skupštine Općine Podravska Slatina i Izvršnoga vijeća. Šimara je dobio zadatak imenovati svoja dva pomoćnika, od kojih mu je jedan imao obvezu pomaganja u stvarima gospodarstva i društvenih djelatnosti, a drugi u stvarima državne uprave.

U svome je radu i djelovanju Šimara bio odgovoran Vladi Republike Hrvatske, a njegovi pomoćnici njemu osobno. Nakon imenovanja organi uprave i drugi državni organi u Općini Podravska Slatina nastavili su s radom pod izravnim nadzorom povjerenika Vlade $\mathrm{RH}$, odnosno njegovih pomoćnika. Šimara je kao povjerenik podnosio izvješće o svome radu i djelovanju Vladi Republike Hrvatske najmanje jedanput mjesečno.

Uvjete za provedbu Naredbe o poduzimanju posebnih mjera u općini Podravska Slatina po potrebi moglo je osiguravati Ministarstvo unutarnjih poslova Republike Hrvatske.

Pomoćnici povjerenika Vlade RH u općini Podravska Slatina za gospodarstvo bili su:

- Josip Fazekaš, dipl ing. iz Podravske Slatine, od 26. srpnja 1991. ${ }^{39}$ do 13. kolovoza $1991 .^{40}$

${ }_{38} \quad$ Na temelju točke 4. Naredbe o poduzimanju posebnih mjera u Općini Podravska Slatina, a u svezi s člankom 17b. stavkom 3. Zakona o Vladi Republike Hrvatske u ime Vlade Republike Hrvatske ministar pravosuđa i uprave Republike Hrvatske donio je 24. srpnja 1991. godine u Zagrebu „Rješenje o imenovanju povjerenika Vlade u općini Podravska Slatina“, Klasa:015-05/91-01/17, Urbroj: 514-01-91-2, Narodne novine, br. 36/1991.

39 „Rješenje povjerenika Vlade Republike Hrvatske u općini Podravska Slatina“, klasa: 01505/91-o1/o2, ubroj: 2166-o1-o1-91-3 od 26. srpnja 1991.

40 „Rješenje povjerenika Vlade Republike Hrvatske u općini Podravska Slatina“, klasa: 01505/91-01/o2, ubroj: 2166-01-01-91-6 od 13. kolovoza 1991. 
- Josip Hrala, dipl. ecc. iz Podravske Slatine, od 18. kolovoza 1991. ${ }^{41}$ do 12. prosinca $1991 .^{42}$

- Krešimir Fučkar, dipl. ecc. iz Sladojevaca, od 16. prosinca $1991 .^{43}$ do 31. kolovoza 1992. ${ }^{44}$

- Matija Perkovac, dipl. ing. iz Donjih Meljana, od 1. rujna 1992. ${ }^{45}$ do 16. travnja 1993. ${ }^{46}$

Pomoćnici povjerenika Vlade RH u općini Podravska Slatina za društvene djelatnosti bili su:

- Ivan Nemet, dr. vet. med. iz Čađavice, od 24. srpnja $1991 .{ }^{47}$ do 31. prosinca $1991 .^{48}$

- Ojkić Milorad, dipl. ecc. iz Podravske Slatine, od 26. srpnja 1991.49 do 13. kolovoza 1991.50

- Ivica Špoljarić, dipl. ecc. iz Podravske Slatine, od 27. siječnja 1992. ${ }^{51}$ do 6. travnja $1992 .{ }^{52}$

${ }_{41}$ „Rješenje povjerenika Vlade Republike Hrvatske u općini Podravska Slatina“, klasa: 01505/91-01/o2, ubroj: 2166-o1-o1-91-7 od 18. kolovoza 1991.

42 „Rješenje povjerenika Vlade Republike Hrvatske u općini Podravska Slatina“, klasa: 01505/91-01/o2, ubroj: 2166-01-01-91-8 od 12. prosinca 1991.

43 „Rješenje povjerenika Vlade Republike Hrvatske u općini Podravska Slatina“, klasa: 01505/91-01/05, ubroj: 2166-01-01-91-1 od 12. prosinca 1991.

44 „Rješenje povjerenika Vlade Republike Hrvatske u općini Podravska Slatina“, klasa: 01505/91-01/o5, ubroj: 2166-01-01-92-2 od 27. kolovoza 1992.

45 „Rješenje povjerenika Vlade Republike Hrvatske u općini Podravska Slatina“, klasa: 01505/92-01/o2, ubroj: 2166-01-01-92-1 od 27. kolovoza 1992.

46 „Rješenje povjerenika Vlade Republike Hrvatske u općini Podravska Slatina“, klasa: 112o3/93-01/42, ubroj: 2166-o1-o1-93-1 od 16. travnja 1993.

47 „Rješenje povjerenika Vlade Republike Hrvatske u općini Podravska Slatina“, klasa: 01505/91-01/o2, ubroj: 2166-o1-o1-91-4 od 26. srpnja 1991.

48 „Rješenje povjerenika Vlade Republike Hrvatske u općini Podravska Slatina“, klasa: 01505/91-01/o2, ubroj: 2166-01-01-91-5 od 30. prosinca 1991.

49 „Rješenje povjerenika Vlade Republike Hrvatske u općini Podravska Slatina“, klasa: 015o5/91-o1/o2, ubroj: 2166-o1-o1-91-2 od 26. srpnja 1991.

50 „Rješenje povjerenika Vlade Republike Hrvatske u općini Podravska Slatina“, klasa: 01505/91-o1/o2, ubroj: 2166-01-o1-91-5 od 13. kolovoza 1991.

${ }^{51}$ „Rješenje povjerenika Vlade Republike Hrvatske u općini Podravska Slatina“, klasa: 11203/92-02/o3, ubroj: 2166-01-01-92-1 od 24. siječnja 1992.

${ }^{52}$ „Rješenje povjerenika Vlade Republike Hrvatske u općini Podravska Slatina“, klasa: 112o3/92-01/o3, ubroj: 2166-01-01-92-2 od 6. travnja 1992. 
- Jozo Medved, prof. iz Podravske Slatine, od 14. travnja $1992 .{ }^{53}$ do 16. travnja $1993 .^{54}$

Pored pomoćnika za gospodarstvo i društvene djelatnosti vrlo kratko postojao je i pomoćnik za područje državne uprave, a ovu je funkciju obnašao Slavo Presečan iz Podravske Slatine od 19. studenoga $1991 .{ }^{55}$ do 16. prosinca $1991 . .^{56}$

\section{Izbori u Slatini prema novomu lokalnom ustrojstvu}

Regionalni i lokalni izbori održani su 7. veljače 1993. te su izabrani vijećnici za županijske skupštine te gradska i općinska vijeća. Prvi izbori u nezavisnoj Republici Hrvatskoj po novome upravnom ustrojstvu održani su na temelju odredaba Ustava Republike Hrvatske, ${ }^{57}$ Zakona o lokalnoj samoupravi i upravij8 i Zakona o područjima županija, gradova i općina u Republici Hrvatskoj. ${ }^{59}$ Nakon provedenih izbora pristupilo se utemeljenju županijskih skupština, gradskih i općinskih vijeća koji su provedeni sredinom travnja.

U Slatini su građani birali između dvije liste; jednu su činili predstavnici HDZ-a, a drugu koalicije HSS-a i SDH-a. Izabrani zastupnici s liste HDZ-a bili su: Željko Peterfelj, Ivan Roštaš, Franjo Kostanjevac, Željko Filković, Ivan Stanek, Vlado Međimurac, Matija Perkovac, Dragutin Pelikan, Vicko Filipović, Mišo Drmić, Zoran Stipanović, Božica Majhen i Ružica Cerić. Na drugoj strani, izabrani zastupnici s liste HSS-a i SDH-a bili su: Zlatko Pripić, Mirko Prevender, Marko Batur, Jadranko Sacher,

53 „Rješenje povjerenika Vlade Republike Hrvatske u općini Podravska Slatina“, klasa: 112o3/92-01/45, ubroj: 2166-o1-01-92-1 od 13. travnja 1992.

54 „Rješenje povjerenika Vlade Republike Hrvatske u općini Podravska Slatina“, klasa: 112o3/93-01/41, ubroj: 2166-o1-01-93-1 od 16. travnja 1993.

55 „Rješenje povjerenika Vlade Republike Hrvatske u općini Podravska Slatina“, klasa: 01505/91-01/o4, ubroj: 2166-01-01-91-2 od 19. studenoga 1991.

56 „Rješenje povjerenika Vlade Republike Hrvatske u općini Podravska Slatina“, klasa: 01505/91-01/o4, ubroj: 2166-01-01-91-3 od 12. prosinca 1991.

57 Narodne novine, br. 56/1990.

${ }_{58} \quad$ Narodne novine, br. 90/1992.

59 Narodne novine, br. 90/1992. 
Dragutin Žilavi, Đuro Horvat, Pavo Čačić, Antun Radočaj, Zvonko Šomođi, Stjepan Jagić, Vesna Ivček, Drago Jelić i Dragutin Plavec. ${ }^{60}$

Ustrojstvo Grada Slatine izvršeno je temeljem Odluke o privremenom ustrojstvu Grada Slatine ${ }^{61}$ i Odluke o privremenom poslovničkom redu Gradskoga vijeća Grada Slatine. ${ }^{62} \mathrm{Na}$ temelju odredaba navedenih odluka Gradsko vijeće Grada Slatine na 1. konstituirajućoj sjednici, održanoj 15. travnja 1993. godine, izabralo je sljedeća tijela i obnašatelje funkcija:

- Mandatna komisija Gradskoga vijeća Grada Slatine u sljedećem sastavu: predsjednik Ivan Roštaš, članovi Zlatko Prpić i Ružica Cerić. ${ }^{63}$

- Odbor za izbor i imenovanje u sljedećem sastavu: predsjednik Matija Perkovac, članovi Željko Peterfaj, Franjo Kostanjevac, Vlado Međimurac i Zoran Stipanić. ${ }^{64}$

- Odbor za Statut i Poslovnik u sljedećem sastavu: predsjednica Vesna Ivček, članovi Mišo Drmić, Zvonko Šomođi, Ivan Stanek i Željko Filković. ${ }^{65}$

- predsjednik Gradskoga vijeća Grada Slatine

- potpredsjednik Gradskoga vijeća Grada Slatine

- gradonačelnik Grada Slatine

- dva zamjenika gradonačelnika.

Konstituirajuća sjednica Gradskoga vijeća Grada Slatine počela je u napetoj atmosferi jer zastupnici HDZ-a i koalicije HSS-a i SDH-a nisu

60 Z. Duka - D. Jirasek - G. Litvan - K. RosanciĆ - B. Sušanj, „Prva stranačka vlada države, tko vlada Hrvatskom“, Večernji list, Zagreb, br. 10591, 15. veljače 1993., str. 17-19.

61 „Odluka o privremenom ustrojstvu Grada Slatine“, klasa: 023-01/93-01/51, ubroj: 2166-o101-93-1 od 15. travnja 1993., Službeni glasnik Grada Slatine, br. 3/1993.

62 „Odluka o privremenom poslovničkom redu Gradskoga vijeća Grada Slatine“, klasa: 02301/93-01/50, ubroj: 2166-o1-o1-93-1 od 15. travnja 1993., Službeni glasnik Grada Slatine, br. 3/1993.

63 „Rješenje o izboru Mandatne komisije Gradskoga vijeća Grada Slatine“, o23-05/93-01/27, ubroj: 2166-01-01-93-1 od 15. travnja 1993., Službeni glasnik Grada Slatine, br. 3/1993.

${ }_{64}$ „Rješenje o izboru Odbora za izbor i imenovanje“, o23-01/93-01/28, ubroj: 2166-01-01-93-1 od 15. travnja 1993., Službeni glasnik Grada Slatine, br. 3/1993.

${ }_{65}$ „Rješenje o izboru Odbora za Statut i Poslovnik“, o23-01/93-01/29, ubroj: 2166-01-01-93-1 od 15. travnja 1993., Službeni glasnik Grada Slatine, br. 3/1993. 
uskladili stavove oko čelnih gradskih funkcija. Slatinsko biračko tijelo podijelilo je po trinaest biračkih mjesta HDZ-u i koaliciji HSS-a i SDH-a. Međutim, troje je predstavnika koalicije optiralo i priklonilo se HDZ-u. Rasprava i usvajanje privremenih odluka o radu Gradskoga vijeća Grada Slatine tekli su po predviđenome protokolu do trenutka kada se pristupilo predlaganju i izboru Izborne komisije koja je trebala predložiti kandidate za rukovodeće gradske funkcije. Oba bloka predložila su svoje liste, a nakon odluke većine vijećnika o prihvaćanju HDZ-ove liste jedanaest vijećnika koalicije HSS-a i SDH-a napustilo je konstituirajuću sjednicu. Preostali vijećnici većinom glasova izabrali su za predsjednicu Gradskoga vijeća Grada Slatine Božicu Majhen, ${ }^{66}$ a za dopredsjednika Zlatka Prpića. ${ }^{67}$ Za gradonačelnika vijećnici su izabrali Ivana Levara, ${ }^{68}$ a za njegove zamjenike Ladislava Tota ${ }^{69}$ i Dragutina Pelikana..$^{71}$

Nakon konstituiranja Gradskoga vijeća Grada Slatine i izbora gradonačelnika i dvaju njegovih zamjenika, ipso iure i ipso facto, prestala je potreba za postojanjem funkcije povjerenika Vlade RH za Općinu Podravska Slatina, ${ }^{72}$ a njegova funkcija i funkcija dvaju njegovih pomoćnika prestale su postojati 15. travnja 1993. godine.

\section{Zaključak}

Nakon blokade rada Izvršnoga vijeća Općinske skupštine Podravska Slatina Ministarstvo pravosuđa i uprave, odnosno resorni ministar prof.

66 „Rješenje o izboru predsjednika Gradskog vijeća Grada Slatine“, o23-01/93-01/30, ubroj: 2166-o1-o1-93-1 od 15. travnja 1993., Službeni glasnik Grada Slatine, br. 3/1993.

${ }_{77}$ „Rješenje o izboru potpredsjednika Gradskog vijeća Grada Slatine“, o23-01/93-01/31, ubroj: 2166-o1-o1-93-1 od 15. travnja 1993., Službeni glasnik Grada Slatine, br. 3/1993.

68 „Rješenje o izboru gradonačelnika Grada Slatine“, O23-01/93-01/32, ubroj: 2166-01-01-93-1 od 15. travnja 1993., Službeni glasnik Grada Slatine, br. 3/1993.

69 „Rješenje o izboru zamjenika gradonačelnika Grada Slatine“, 023-01/93-01/33, ubroj: 216601-o1-93-1 od 15. travnja 1993., Službeni glasnik Grada Slatine, br. 3/1993.

70 „Rješenje o izboru zamjenika gradonačelnika Grada Slatine“, o23-01/93-01/34, ubroj: 216601-01-93-1 od 15. travnja 1993., Službeni glasnik Grada Slatine, br. 3/1993.

${ }_{71}$ Šantoši, D.: „Odluka u posljednji čas“, Večernji list, br. 10 651, 16. travnja 1993., str. 11.

72 „Odluka o promjeni naziva naselja Podravska Slatina, povjerenik Vlade Republike Hrvatske u općini Podravska Slatina“, klasa: 363-01/93-01/o1, ubroj: 2166-01-01-93-1 od 1. veljače 1993., Službeni glasnik općine Podravska Slatina, br. 1/1993. 
dr. sc. Branko Babac, donio je sudbonosnu Naredbu o poduzimanju posebnih mjera u općini Podravska Slatina kojom je raspuštena Skupština Općine Podravska Slatina, a istovremeno je imenovao Antu Šimaru povjerenikom Vlade Republike Hrvatske u Općini Podravska Slatina. Ovim činom ministar Babac stvorio je preduvjete za normalizaciju života u Općini Podravska Slatinka. S druge strane, stvorio je normativne preduvjete za organizaciju obrane u općini.

Nakon što je Ante Šimara imenovan povjerenikom Vlade Republike Hrvatske u Općini Podravska Slatina, njegov prvi bitniji političko-sigurnosni potez dogodio se 30. rujna 1991. godine kada je na temelju odredaba točke 3. Odluke o kriznim štabovima i točke 5. Naredbe o poduzimanju posebnih mjera u općini Podravska Slatina donio Rješenje o osnivanju i imenovanju članova Kriznoga štaba za općinu Podravska Slatina. Tim činom Šimara je ujedinio djelovanje svih institucija civilne vlasti i gospodarstva, a u cilju obrane suvereniteta i teritorijalnoga integriteta Republike Hrvatske na području bivše Općine Podravska Slatina. Krizni štab odigrao je dominantnu ulogu tijekom Domovinskoga rata na slatinskome području. Izvrsno je ujedinio civilnu i vojnu komponentu u pružanju zdravstvene skrbi, pomoći u životnim potrepštinama izbjegloga pučanstva i logistici u vojnim postrojbama i civilnoj zaštiti. Slatinsko je područje među prvim u Republici Hrvatskoj oslobođeno, zadnji pripadnik neprijateljskih postrojbi je u vojno-redarstvenoj akciji „Papu“ protjeran 14. prosinca 1991.

Nakon oslobođenja Šimara je stvorio preduvjete za održavanje prvih višestranačkih izbora na mjesnoj razini u gradu Slatini i novoformiranim općinama Voćin, Čađavica, Sopje, Nova Bukovica i Mikleuš. 
Review article

Received November 6., 2017

Miljenko Brekalo

Institute of Social Sciences Ivo Pilar, Regional Center Osijek

\section{LEGAL ASPECTS OF APPOINTING THE COMMISSIONER OF THE CROATIAN GOVERNMENT IN THE MUNICIPALITY OF PODRAVSKA SLATINA}

\section{Abstract}

The Serbian Democratic Party (SDS) was a radical ethnic-nationalist Serbian party, founded on the platform in front of the railway station in Knin on February 17, 1990 and registered in the Register of Social Organizations of the Socialist Republic of Croatia on March 6, 1990. The Founding Assembly was attended by seven thousand citizens of Serbian nationality, who gave their support to the program document by acclamation. Academician Jovan Raskovic, a psychiatrist from Sibenik, founded SDS under control of the Serbian State Security Sevice ("SDB"), at that time led by the Hague indictee Jovica Stanisic, a faithful Milosevic follower.

SDS had a leading political role in war events in Croatia and Bosnia and Herzegovina. Its members organized the arming of Serbs, supported killing, expelling and other war crimes against non-Serbs in the territory of Croatia and Bosnia and Herzegovina. SDS Municipal Committee for the Municipality of Podravska Slatina headed by Milun Karadic organized the arming of Serbs in the area of the Municipality of Podravska Slatina, expressed civil disobedience and blocked the functioning of the Municipal Assembly of Podravska Slatina. After SDS had blocked the function of the Executive Council of the Municipal Assembly of Podravska Slatina, a reaction came from the Justice and Administration Minister Branko Babac. On July 24, 1991 he issued the Order to take special measures in the Municipality of Podravska Slatina, whereupon the Assembly of 
the Municipality of Podravska Slatina was dissolved and a Commissioner of the Croatian Government was appointed at the same time.

Keywords: Republic of Croatia; Serbian Democratic Party; Municipality of Podravska Slatina; Executive Council of the Municipal Assembly of Podravska Slatina; Commissioner of the Croatian Government; State Security Service 